\title{
Methods of breaking seed dormancy for ornamental passion fruit species ${ }^{(1)}$
}

\author{
THALITA NEVES MAROSTEGA(2), PETTERSON BAPTISTA DA LUZ(3), ARMANDO REIS TAVARES ${ }^{(4)}$, \\ LEONARDA GRILLO NEVES ${ }^{(3)}$ and SEVERINO DE PAIVA SOBRINHO ${ }^{(3)}$
}

\begin{abstract}
The Passiflora L. genus covers a diversity of wild species with ornamental potential, especially due to the intrinsic beauty of its exotic flowers, flowering more than once a year and the lush foliage. However, Passiflora seeds present dormancy complicating seed germination and the establishment of commercial plant production with species with high ornamental potential. This study was conducted to determine the best pre-germination treatments to overcome seed dormancy for Passiflora quadrangularis, $P$. nitida, P. foetida, P. eichleriana, P. alata, P. cincinnata, P. mucronata, P. micropetala, P. suberosa, P. morifolia and P. tenuifila. The experimental design was completely randomized, with five treatments and four replicates, with 25 seeds per plot. Pre-germination treatments were: seeds soaked in $1,000 \mathrm{mg} \mathrm{L}^{-1} \mathrm{GA}_{3}$ (gibberellic acid) for 6 hours, seeds soaked in $0.2 \% \mathrm{KNO}_{3}$ (potassium nitrate) for 24 hours, seeds soaked in $1 \% \mathrm{KNO}_{3}$ for 24 hours, partial seedcoat scarification with sandpaper number 120 and control (seeds untreated). Percentage of germination, germination velocity index and radicle length were evaluated for all species. The results showed that $\mathrm{GA}_{3}$ was effective to overcome seed dormancy in P. suberosa (86\%), P. morifolia (68\%) and P. tenuifila $(54 \%)$. $\mathrm{KNO}_{3}$ $1 \%$ had significant effect on overcoming dormancy in seeds of $P$. eichleriana $(66 \%)$ and scarification with sandpaper increased seed germination of P. micropetala (38\%).
\end{abstract}

Keywords: Passiflora, germination, vigor, gibberellic acid, potassium nitrate, mechanical scarification

\section{RESUMO}

Tratamentos pré-germinativos para a quebra de dormência de sementes de espécies ornamentais de maracujá O gênero Passiflora L. abrange uma diversidade de espécies selvagens com potencial ornamental, especialmente devido à beleza intrínseca de suas flores exóticas, florescer mais do que uma vez por ano e a folhagem exuberante. No entanto, sementes de Passiflora apresentam dormência, dificultando a germinação das sementes e o estabelecimento de produção comercial de plantas com espécies com elevado potencial ornamental. Este estudo foi realizado para determinar o melhor tratamento pré-germinativo visando superar a dormência das sementes das espécies Passiflora quadrangularis, P. nitida, P. foetida, P. eichleriana, $P$. alata, P. cincinnata, P. mucronata, P. micropetala, P. suberosa, P. morifolia e P. tenuifila. O delineamento experimental foi inteiramente casualizado, com cinco tratamentos e quatro repetições, com 25 sementes por parcela. Os tratamentos foram: pré-germinação das sementes embebidas em $1.000 \mathrm{mg} \mathrm{L}^{-1}$ de $\mathrm{GA}_{3}$ (ácido giberélico) durante 6 horas, sementes embebidas em $0,2 \%$ de $\mathrm{KNO}_{3}$ (nitrato de potássio) durante 24 horas, sementes embebidas em $1 \%$ de $\mathrm{KNO}_{3}$ durante 24 horas, escarificação mecânica com lixa número 120 e Controle (sementes não tratadas). Foram avaliadas a porcentagem de germinação, índice de velocidade de germinação e o comprimento radicular para todas as espécies. Os resultados mostraram que o $\mathrm{GA}_{3}$ foi eficaz para quebrar a dormência da semente em P. suberosa (86\%), P. morifolia (68\%) e P. tenuifila (54\%). O tratamento $\mathrm{KNO}_{3} 1 \%$ teve efeito significativo sobre a quebra de dormência em sementes de $P$. eichleriana $(66 \%)$ e a escarificação com lixa aumentou a germinação das sementes de P. micropetala (38\%).

Palavras-chave: Passiflora, germinação, vigor, ácido giberélico, nitrato de potássio, escarificação mecânica.

\section{INTRODUCTION}

Passion fruit can be propagated by asexual reproduction as cuttings, grafting, layering or tissue culture (FERREIRA, 2000). Nevertheless, passion fruit vines are usually propagated from seeds, ensuring plant health as crop diseases are not transmitted by seed (MELETTI et al., 2002). Seed propagation is also recommended for rootstock formation and plant breeding programs focused on disease-resistant and drought-tolerant hybrids with ornamental or medicinal use (JUNQUEIRA et al., 2001).

Several authors had reported that the period for passion fruit germination is from ten days to three months, with low germination rate and irregular seedling formation (DELANOY et al. 2006; FOWLER and BIANCHETTI, 2000; DOIJODE, 2001). Some species show seed dormancy, which may be physical (seed coat impermeability to water and gases), chemical (presence of inhibiting substances),

DOI: http://dx.doi.org/10.14295/oh.v23i1.982

(1) Received in 21/10/2016 and accepted in 09/02/2017

${ }^{(2)}$ Universidade do Estado de Mato Grosso (UNEMAT), Programa de Pós-graduação em Genética e Melhoramento de Plantas, Cáceres-MT, Brazil.

(3)Universidade do Estado de Mato Grosso (UNEMAT), Cáceres-MT, Brazil. *Corresponding author: petterbaptista@yahoo.com.br

${ }^{(4)}$ Instituto de Botânica (IBt), São Paulo-SP, Brazil. 
mechanical (tegument resistance to embryo growth) or even physiological factors (mechanisms of germination inhibition) (FOWLER and BIANCHETTI, 2000). The period of seed viability for the majority of Passiflora species is unknown (FALEIRO et al., 2005), and the long period of natural or induced dormancy make seed germination slow and unevenness, restricting the commercial use of promising materials (DOIJODE, 2001).

Considering the number of Passiflora species and increasing use of these species as a resource for breeding programs of passion fruit and for ornamental, medicinal, and food purposes, this research aimed to overcome seed dormancy of 11 Passiflora species by pre-germination treatments as physical scarification and soaking in gibberellic acid and potassium nitrate solutions.

\section{MATERIAL AND METHODS}

The commercial seeds of Passiflora alata and ten wild species, P. quadrangularis, P. nitida, P. foetida, P. eichleriana, P. cincinnata, . mucronata, $P$. micropetala, $P$. suberosa, $P$. morifolia, and $P$. tenuifila were evaluated (Figure 1).

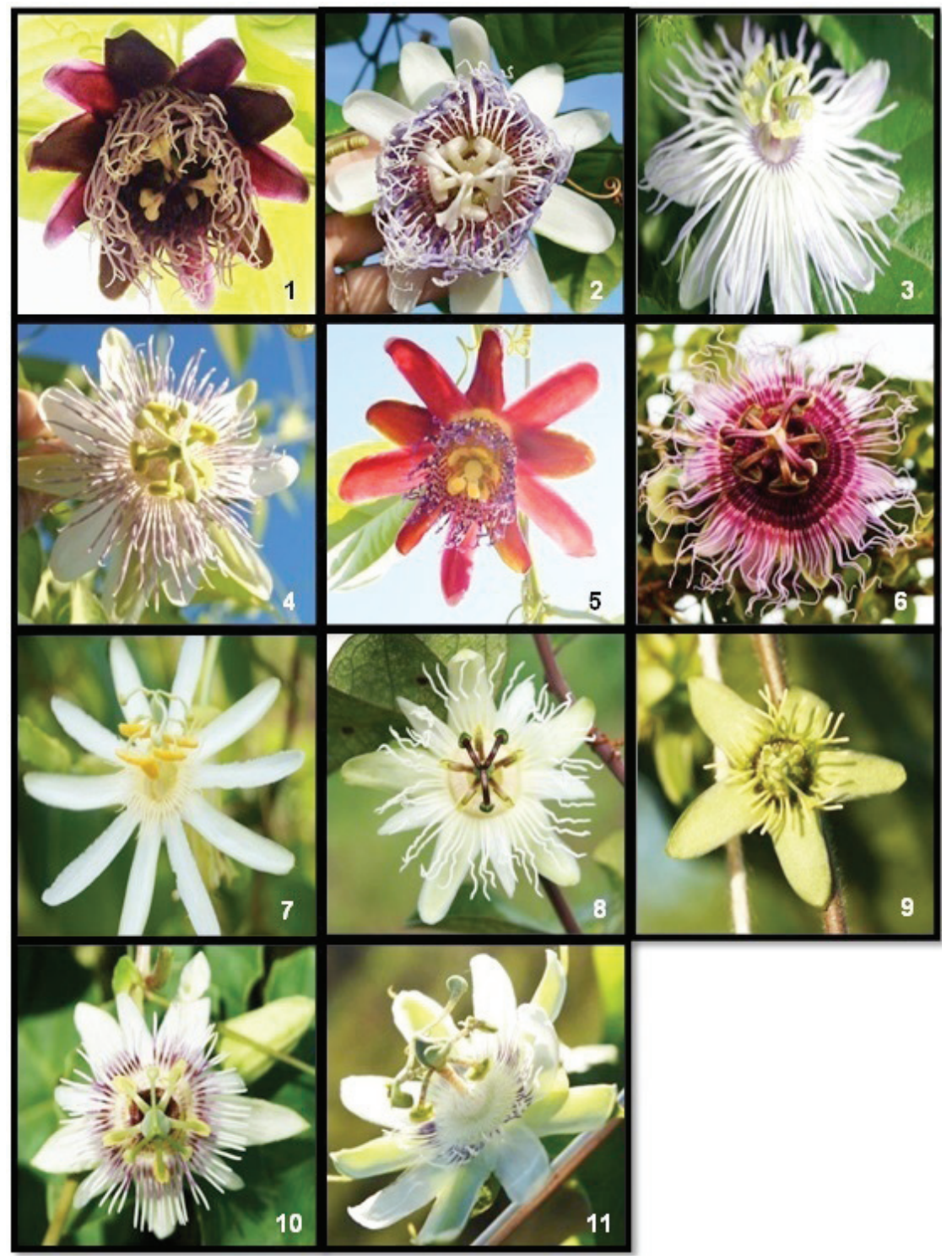

Figure 1. Flowers of 1) P. quadrangularis, 2) P. nitida, 3) P. foetida, 4) P. eichleriana, 5) P. alata, 6) P. cincinnata, 7) P. mucronata,

8) P. micropetala, 9) P. suberosa, 10) P. morifolia, 11) P. tenuifila.

Passion fruit seeds resultant of natural pollination were collected from ripped fruits. After fruit harvest and pulp extraction, the mucilaginous arillus was removed by rubbing the seeds with water across a wire sieve (3$\mathrm{mm}$ mesh); then they were washed and left to shade dry on paper towels for two days at room temperature. Seed moisture level was determined by the oven method at 105 ${ }^{\circ} \mathrm{C} \pm 3$ for 24 hours (BRASIL, 2009). Before germination test, seeds were sterilized with alcohol solution $(70 \%$ $\mathrm{v} / \mathrm{v})$ for one minute, and sodium hypochlorite $(2.5 \%$ active chlorine) for 5 minutes, afterwards washed in distilled water. 
The experiment was performed in a completely randomized design with five treatments and four replications with 25 seeds per plot. Pre-germination treatments were seeds soaked in 1,000 $\mathrm{mg} \mathrm{L}^{-1} \mathrm{GA}_{3}$ (Gibberellic Acid) for 6 hours, seeds soaked in $\mathrm{KNO}_{3} 0.2 \%$ for 24 hours, seeds soaked in $\mathrm{KNO}_{3} 1 \%$ for 24 hours, partial seedcoat scarification with sandpaper number 120 and Control (seeds untreated).

Seeds were transferred to transparent polyethylene boxes ("Gerbox"), within three paper towel sheets ("Germitest") moistened with distilled water at a ratio of two and a half times of paper weight (BRASIL, 2009). The boxes were placed in transparent polyethylene bags and kept in germination chamber for 30 days at $20-30{ }^{\circ} \mathrm{C}$ alternate temperatures, and a 12 -hour photoperiod until the end of the experiment.

Germination percentage (GERM) was daily performed and considered germinated when seed coat was broken and radicle came off, reaching at least $2 \mathrm{~mm}$ long. Radicle length (RL) was measure on normal seedlings and seed vigor was evaluate with Seed Germination Index (SGI) as proposed by Maguire (1962).
Normality was assessed using the KolmogorovSmirnov test with GENES software (CRUZ, 2013). As long as data normality was stated, means underwent variance analysis and were subsequently compared by Tukey test at $5 \%$ of probability using SISVAR software (FERREIRA, 2008).

\section{RESULTS AND DISCUSSION}

Seed moisture level of Passiflora species was (\%): Passiflora alata - 7.70, P. quadrangularis - 9.30, P. nitida - 9.73, P. foetida - 7.82, P. eichleriana - 8.52, P. cincinnata - 9.44, P. mucronata - 9.92, P. micropetala - 13.01, P. suberosa - 8.26, P. morifolia - 11.47, and P. tenuifila - 9.30. The best germination rates for Passiflora edulis 'flavicarpa' seeds are 10\% (MARTINS et al., 2005) and levels above $17 \%$ prejudice the maintenance of its physiological potential (FONSECA and SILVA, 2005).

Table 1 shows the results of germination test (GERM), germination speed index (GSI) and radicle length (RL) for five pre-germinated treatments applied to 11 Passiflora species seeds.

Table 1. Means of germination test (GERM), germination speed index (GSI) and radicle length (RL), after pre-germinated treatments to 11 Passiflora species.

\begin{tabular}{|c|c|c|c|}
\hline Treatments & GERM (\%) & GSI (\%) & RL (cm) \\
\hline & \multicolumn{3}{|c|}{ P. quadrangularis } \\
\hline $\mathrm{GA}_{3}$ & $0 \mathrm{~b}$ & $0.00 \mathrm{c}$ & $0.00 \mathrm{~b}$ \\
\hline $\mathrm{KNO}_{3} 0.2 \%$ & $7 \mathrm{a}$ & $0.11 \mathrm{~b}$ & $2.12 \mathrm{a}$ \\
\hline $\mathrm{KNO}_{3} 1 \%$ & $8 \mathrm{a}$ & $0.15 \mathrm{a}$ & $2.18 \mathrm{a}$ \\
\hline Mechanical Scarification & $0 \mathrm{~b}$ & $0.00 \mathrm{c}$ & $0.00 \mathrm{~b}$ \\
\hline Control & $0 \mathrm{~b}$ & $0.00 \mathrm{c}$ & $0.00 \mathrm{~b}$ \\
\hline \multirow[t]{2}{*}{ CV (\%) } & 29.81 & 28.40 & 7.29 \\
\hline & \multicolumn{3}{|c|}{ P. nitida } \\
\hline $\mathrm{GA}_{3}$ & $26 \mathrm{a}$ & $0.20 \mathrm{a}$ & $3.00 \mathrm{a}$ \\
\hline $\mathrm{KNO}_{3} 0.2 \%$ & $2 \mathrm{~b}$ & $0.01 \mathrm{~b}$ & $0.22 \mathrm{c}$ \\
\hline $\mathrm{KNO}_{3} 1 \%$ & $24 \mathrm{a}$ & $0.16 \mathrm{a}$ & $1.52 \mathrm{~b}$ \\
\hline Mechanical Scarification & $0 \mathrm{~b}$ & $0.00 \mathrm{~b}$ & $0.00 \mathrm{c}$ \\
\hline Control & $0 \mathrm{~b}$ & $0.00 \mathrm{~b}$ & $0.00 \mathrm{c}$ \\
\hline \multirow[t]{2}{*}{ CV $(\%)$} & 37.16 & 32.9 & 21.61 \\
\hline & \multicolumn{3}{|c|}{ P. foetida } \\
\hline $\mathrm{GA}_{3}$ & $15 \mathrm{ab}$ & $1.02 \mathrm{ab}$ & $1.83 \mathrm{a}$ \\
\hline $\mathrm{KNO}_{3} 0.2 \%$ & $27 \mathrm{ab}$ & $1.90 \mathrm{ab}$ & $2.26 \mathrm{a}$ \\
\hline $\mathrm{KNO}_{3} 1 \%$ & $32 \mathrm{a}$ & $2.02 \mathrm{ab}$ & $1.82 \mathrm{a}$ \\
\hline Mechanical Scarification & $13 \mathrm{~b}$ & $0.91 \mathrm{~b}$ & $2.66 \mathrm{a}$ \\
\hline Control & $31 \mathrm{a}$ & $2.30 \mathrm{a}$ & $2.55 \mathrm{a}$ \\
\hline \multirow[t]{2}{*}{ CV $(\%)$} & 34.74 & 36.79 & 23.90 \\
\hline & \multicolumn{3}{|c|}{ P. eichleriana } \\
\hline $\mathrm{GA}_{3}$ & $19 \mathrm{~b}$ & $0.66 \mathrm{~b}$ & $2.96 \mathrm{ab}$ \\
\hline $\mathrm{KNO}_{3} 0.2 \%$ & $36 \mathrm{~b}$ & $1.22 \mathrm{~b}$ & $3.09 \mathrm{ab}$ \\
\hline $\mathrm{KNO}_{3} 1 \%$ & $66 \mathrm{a}$ & $2.58 \mathrm{a}$ & $2.18 \mathrm{~b}$ \\
\hline Mechanical Scarification & $31 \mathrm{~b}$ & $0.95 \mathrm{~b}$ & $3.73 \mathrm{a}$ \\
\hline Control & $39 \mathrm{~b}$ & $1.36 \mathrm{~b}$ & $3.88 \mathrm{a}$ \\
\hline CV $(\%)$ & 24.07 & 28.49 & 19.10 \\
\hline
\end{tabular}


Table 1. cont.

\begin{tabular}{|c|c|c|c|}
\hline & \multicolumn{3}{|c|}{ P. alata } \\
\hline $\mathrm{GA}_{3}$ & $24 \mathrm{a}$ & $0.45 \mathrm{a}$ & $2.23 \mathrm{a}$ \\
\hline $\mathrm{KNO}_{3} 0.2 \%$ & $9 \mathrm{~b}$ & $0.15 \mathrm{~b}$ & $1.75 \mathrm{~b}$ \\
\hline $\mathrm{KNO}_{3} 1 \%$ & $7 \mathrm{~b}$ & $0.09 \mathrm{~b}$ & $2.05 \mathrm{a}$ \\
\hline Mechanical Scarification & $0 \mathrm{c}$ & $0.00 \mathrm{c}$ & $0.00 \mathrm{c}$ \\
\hline Control & $0 \mathrm{c}$ & $0.00 \mathrm{c}$ & $0.00 \mathrm{c}$ \\
\hline \multirow[t]{2}{*}{ CV (\%) } & 24.15 & 31.93 & 9.74 \\
\hline & \multicolumn{3}{|c|}{ P. cincinnata } \\
\hline $\mathrm{GA}_{3}$ & $8 \mathrm{a}$ & $0.25 \mathrm{a}$ & $2.04 \mathrm{~b}$ \\
\hline $\mathrm{KNO}_{3} 0.2 \%$ & $0 \mathrm{c}$ & $0.00 \mathrm{c}$ & $0.00 \mathrm{c}$ \\
\hline $\mathrm{KNO}_{3} 1 \%$ & $4 \mathrm{~b}$ & $0.13 \mathrm{~b}$ & $3.46 \mathrm{a}$ \\
\hline Mechanical Scarification & $0 \mathrm{c}$ & $0.00 \mathrm{c}$ & $0.00 \mathrm{c}$ \\
\hline Control & $0 \mathrm{c}$ & $0.00 \mathrm{c}$ & $0.00 \mathrm{c}$ \\
\hline \multirow[t]{2}{*}{ CV (\%) } & 0 & 13.95 & 14.64 \\
\hline & \multicolumn{3}{|c|}{ P. mucronata } \\
\hline $\mathrm{GA}_{3}$ & $0 \mathrm{~b}$ & $0.00 \mathrm{~b}$ & $0.00 \mathrm{~b}$ \\
\hline $\mathrm{KNO}_{3} 0.2 \%$ & $0 \mathrm{~b}$ & $0.00 \mathrm{~b}$ & $0.00 \mathrm{~b}$ \\
\hline $\mathrm{KNO}_{3} 1 \%$ & $33 \mathrm{a}$ & $1.06 \mathrm{a}$ & $2.44 \mathrm{a}$ \\
\hline Mechanical Scarification & $0 \mathrm{~b}$ & $0.00 \mathrm{~b}$ & $0.00 \mathrm{~b}$ \\
\hline Control & $0 \mathrm{~b}$ & $0.00 \mathrm{~b}$ & $0.00 \mathrm{~b}$ \\
\hline \multirow[t]{2}{*}{ CV (\%) } & 34.10 & 23.66 & 7.85 \\
\hline & \multicolumn{3}{|c|}{ P. micropetala } \\
\hline $\mathrm{GA}_{3}$ & $0 \mathrm{c}$ & $0.00 \mathrm{c}$ & $0.00 \mathrm{~d}$ \\
\hline $\left.\mathrm{KNO}_{3} 0.2 \%\right)$ & $12 \mathrm{~b}$ & $0.22 \mathrm{~b}$ & $6.13 \mathrm{a}$ \\
\hline $\mathrm{KNO}_{3} 1 \%$ & $13 \mathrm{~b}$ & $0.17 \mathrm{~b}$ & $2.99 \mathrm{c}$ \\
\hline Mechanical Scarification & $38 \mathrm{a}$ & $0.61 \mathrm{a}$ & $5.01 \mathrm{~b}$ \\
\hline Control & $0 \mathrm{c}$ & $0.00 \mathrm{c}$ & $0.00 \mathrm{~d}$ \\
\hline \multirow[t]{2}{*}{ CV $(\%)$} & 30.39 & 36.31 & 7.76 \\
\hline & \multicolumn{3}{|c|}{ P. suberosa } \\
\hline $\mathrm{GA}_{3}$ & $86 \mathrm{a}$ & $2.25 \mathrm{a}$ & $2.12 \mathrm{c}$ \\
\hline $\mathrm{KNO}_{3} 0.2 \%$ & $79 a b$ & $1.50 \mathrm{~b}$ & $2.61 \mathrm{bc}$ \\
\hline $\mathrm{KNO}_{3} 1 \%$ & $70 \mathrm{bc}$ & $1.36 \mathrm{~b}$ & $2.85 \mathrm{ab}$ \\
\hline Mechanical Scarification & $62 \mathrm{~cd}$ & $1.56 \mathrm{ab}$ & $3.33 \mathrm{a}$ \\
\hline Control & $49 \mathrm{~d}$ & $1.86 \mathrm{ab}$ & $3.12 \mathrm{ab}$ \\
\hline \multirow[t]{2}{*}{ CV (\%) } & 9.02 & 19.15 & 9.79 \\
\hline & \multicolumn{3}{|c|}{ P. morifolia } \\
\hline $\mathrm{GA}_{3}$ & 68 a & $2.49 \mathrm{a}$ & $1.80 \mathrm{a}$ \\
\hline $\mathrm{KNO}_{3} 0.2 \%\left(\mathrm{KNO}_{3} 0.2 \%\right)$ & $0 \mathrm{~b}$ & $0.00 \mathrm{~b}$ & $0.00 \mathrm{~b}$ \\
\hline $\mathrm{KNO}_{3} 1 \%$ & $0 \mathrm{~b}$ & $0.00 \mathrm{~b}$ & $0.00 \mathrm{~b}$ \\
\hline Mechanical Scarification & $0 \mathrm{~b}$ & $0.00 \mathrm{~b}$ & $0.00 \mathrm{~b}$ \\
\hline Control & $0 \mathrm{~b}$ & $0.00 \mathrm{~b}$ & $0.00 \mathrm{~b}$ \\
\hline \multirow[t]{2}{*}{ CV (\%) } & 21.48 & 11.09 & 10.36 \\
\hline & \multicolumn{3}{|c|}{ P. tenuifila } \\
\hline $\mathrm{GA}_{3}$ & $54 \mathrm{a}$ & $1.46 \mathrm{a}$ & $2.09 \mathrm{a}$ \\
\hline $\mathrm{KNO}_{3} 0.2 \%$ & $0 \mathrm{~b}$ & $0.00 \mathrm{~b}$ & $0.00 \mathrm{~b}$ \\
\hline $\mathrm{KNO}_{3} 1 \%$ & $0 \mathrm{~b}$ & $0.00 \mathrm{~b}$ & $0.00 \mathrm{~b}$ \\
\hline Mechanical Scarification & $0 \mathrm{~b}$ & $0.00 \mathrm{~b}$ & $0.00 \mathrm{~b}$ \\
\hline Control & $0 \mathrm{~b}$ & $0.00 \mathrm{~b}$ & $0.00 \mathrm{~b}$ \\
\hline CV (\%) & 21.38 & 31.11 & 11.48 \\
\hline
\end{tabular}

Means followed by the same letter in the columns do not differ from each other by the Tukey test at $5 \%$ probability. 


\section{P. quadrangularis}

Seeds of Passiflora quadrangularis germinated only in $\mathrm{KNO}_{3} 1 \%$ and $\mathrm{KNO}_{3} 0.2 \%$ treatments, with $8 \%$ and $7 \%$ of seed germination, respectively. Radicles length were statically higher for $\mathrm{KNO}_{3}, 0.2 \%$ and $\mathrm{KNO}_{3}, 1 \%$ with means from 2.12 to $2.18 \mathrm{~cm}$, respectively. However, $\mathrm{KNO}_{3}$ $1 \%$ presented a higher GSI (0.15), compared to $\mathrm{KNO}_{3}$ $0.2 \%(0.11)$. Few studies have been carried to describe $P$. quadrangularis seed germination; as Pereira and Dias (2000) reported that seed germination is uneven for the species with a low germination rate, delaying seedling formation and the production of plants with a desirable quality level. The species in the nature due to the reduced germination rate is rarely found (LORENZI, 2006).

\section{P. nitida}

Seed germination of $P$. nitida was statically higher for $\mathrm{GA}_{3}(26 \%)$ and $\mathrm{KNO}_{3} 1 \%(24 \%)$, with GSI of 0.20 and 0.16 , respectively. Radicle length of $\mathrm{GA}_{3}$ treatment $(3.0 \mathrm{~cm})$ was higher than $\mathrm{KNO}_{3} 1 \%(1.52 \mathrm{~cm})$. Control and mechanical scarification have not promoted germination, as well as $\mathrm{KNO}_{3} 0.2 \%$, with only $2 \%$ of germinated seeds. Research for this species is still incipient; although the studies shows that newly harvested seeds have low germination (1\%) regardless of arillus removal method and after four-month storage germination was increased to $25 \%$ and after nine months reached $60 \%$ and after thirteen months seeds no longer germinated (MELO, 1998). Nevertheless, Passos et al. (2004), using $P$. nitida seeds stored for two years and five months, observed a rate of $86 \%$ of seed germination receiving $\mathrm{GA}_{3}$ treatment $\left(1,000 \mathrm{mg} \mathrm{L}^{-1}\right)$ at 50 -day trial.

\section{P. foetida}

$\mathrm{KNO}_{3}, 1 \%$ and control had the highest germination rate for $P$. foetida seeds with $32 \%$ and $31 \%$, respectively. Mechanical scarification have had the lower GSI $(0.91 \mathrm{~cm})$ and GERM\% (13\%), showing seed scarification was prejudicial for $P$. foetida seed germination. Radicle length have not had statistical difference from treatments, showing 2.66 to $1.82 \mathrm{~cm}$ to mechanical scarification and $\mathrm{KNO}_{3} 1 \%$, respectively. All pre-germination methods applied for $P$. foetida seeds had no effect, and were statically equivalent to control, thus the seeds germinated on all treatments. Santos et al. (2012) reported interspecific hybridizations have been carried with $P$. foetida because besides having an ornamental potential, it has a high germination speed; however, such fact was not observed in the current study.

\section{P. eichleriana}

To overcome $P$. eichleriana seed dormancy, $\mathrm{KNO}_{3}, 1 \%$ shown to be effective, with germination rate of $66 \%$ and GSI of 2.58, differing statistically from others treatments. Control showed the highest radicle length $(3.88 \mathrm{~cm})$. There are no studies about $P$. eichleriana seed germination; such data can substantially contribute to its propagation.

\section{P. alata}

$P$. alata presents physiological seed dormancy as control and mechanical scarification had not promoted seed germination. $\mathrm{GA}_{3}, \mathrm{KNO}_{3} 0.2 \%$ and $\mathrm{KNO}_{3} 1 \%$ treatments promoted $P$. alata seed germination. Treatment with $\mathrm{GA}_{3}$ increased seed germination rate $(24 \%)$, GSI (0.45) and radicle length $(2.23 \mathrm{~cm})$. Ferreira et al. (2001) observed that $\mathrm{GA}_{3}\left(500 \mathrm{mg} \mathrm{L}^{-1}\right)$ increased seed germination of $P$. alata. Additionally, Rossetto et al. (2000) showed that 150 and 300 ppm of $\mathrm{GA}_{3}$ had higher germination rates and speed index in fresh passion fruit seeds, when compared to the control treatment.

\section{P. cincinnata}

P. cincinnata seed germination was low for all treatments and reached the higher value $(8 \%)$ with $\mathrm{GA}_{3}$ treatment. $\mathrm{GA}_{3}$ has shown the higher value for GSI $(0.25)$ and $1 \% \mathrm{KNO}_{3}$ the greater radicle length (3.46). The low germination rate of $P$. cincinnata might be related to its elevated dormancy level (MELETTI et al., 2002). Such dormancy is related to seed hormonal balance, since $\mathrm{GA}_{3}$ showed the best results. The magnitude of $\mathrm{GA}_{3}$ effect became clear when it was detected that embryos synthesize gibberellin and release them to endosperm during seed germination, accelerating the radicle and shoot development (ROBERTS and MILK, 2004).

\section{P. mucronata}

P. mucronata seeds only germinated on $\mathrm{KNO}_{3} 1 \%$ treatment $(33 \%)$, thus the treatment had higher GSI (1.06) and RL (2.44) values. However, Santos et al., 2012 observed that fresh seeds of $P$. mucronata had a high germination potential $(72 \%)$ without any pre-germination treatment, but after four months of seed storage the germination rate decay to zero, and a secondary dormancy mechanism may be involved to prevent seed germination of this species. A secondary dormancy occurs when the cotyledon is moistness and promote germination-inhibiting substances on the embryonic axis inhibiting germination and consequently maintaining dormancy (BEWLEY and BLACK, 1994).

\section{P. micropetala}

The best treatment to overcome seed dormancy of $P$. micropetala was mechanical scarification with $38 \%$ of germination. GSI for $0.61 \mathrm{KNO}_{3} 0.2 \%$ was higher than all treatments for radicle length (6.13). P. micropetala seeds have an integumentary dormancy, so scarifying techniques can favor water entrance and subsequently faster reactivation of metabolic system, therefore increasing germination (WAGNER JÚNIOR et al., 2006).

\section{P. suberosa}

The greatest germination rate of $P$. suberosa was observed for $\mathrm{GA}_{3}$ treatment with $86 \%$. GA 3 also have had the best result for GSI (2.25), followed by control (1.86) and mechanical scarification (1.56). Mechanical scarification (3.33) and control (3.12) were superior to the others treatments for radicle length. Caldas et al. (2008), assessing in vitro germination of $P$. suberosa seeds treated with $\mathrm{GA}_{3}(1,000 \mathrm{ppm})$ for 3 hours, presented $13 \%$ of seeds germinated and, $30 \%$ of germination for seeds treated with $\mathrm{KNO}_{3} 20 \%$ (SOUZA, 2015). 


\section{P. morifolia}

Passiflora morifolia seeds presented physiological dormancy mechanism, once only $\mathrm{GA}_{3}$ treatment promoted seed germination (68\%). Gibberellic acid stimulates the synthesis of enzymes such as alpha and beta amylase, acting on seed mobilization to form sugars, amino acids and nucleic acids, that area absorbed and transported to embryo growth regions, stimulating cell elongation and, accelerating and standardizing germination (TAIZ and ZEIGER, 2009).

\section{P. tenuifila}

As observed for $P$. morifolia, in P. tenuifila $\mathrm{GA}_{3}$ was the only treatment that stimulate seed germination (54\%). $P$. tenuifila is very important specie for passion-flower breeding given the importance of the species due to its resistance/tolerant for soil diseases, however there is a lack of information in the literature regarding overcoming its dormancy (FALEIRO et al., 2005).

Seed dormancy is an important adaptive mechanism in many species and it is, generally, lost during plant domestication and can be classified as physiological, morphological, morphophysiological, physical and combinational dormancy (BASKIN and BASKIN, 2004). Physiological dormancy is caused by endogenous factors and responds to heat or hormonal treatment, morphological is caused by immature embryos and physical is caused by a layer that is impermeable to water (MENDIONDO and GARCÍA, 2006). Our results show that all species except $P$. micropetala were able to germinate regardless of scarification, though the tegument does not seem to represent a barrier to water penetration into the seeds, thus do not constitute a case of physical dormancy as observed for the other Passiflora species. P. foetida have not shown seed dormancy, as germination percentage to control was higher than other treatments. $P$. quadrangularis, $P$. nitida, P. cincinnata, P. mucronata, P. micropetala and $P$. tenuifila have not germinated without pre-germination treatment presenting seed dormancy. Passiflora species can be divided in two groups concerning to the dormancy type: $P$. quadrangularis, $P$. nitida, $P$. alata, $P$. cincinnata, P. mucronata, P. morifolia and $P$. tenuifila with chemical dormancy and responsive to chemical composts as $\mathrm{GA}_{3}$ and/or $\mathrm{KNO}_{3}$, and $P$. foetida, P. eichleriana, P. micropetala, and $P$. suberosa with chemical and/or mechanical dormancy. Exogenous dormancy, probably a combination of mechanical and chemical dormancy is present in Passiflora (DELANOY et al., 2006). Seed dormancy is one of the most important phenomena for wild species evolution to overcome adverse environmental conditions and to colonize new habitats of unsuitable growth. Our study attempt to bring information regarding Passiflora seed germination and provide basic study to further refinement knowledge about overcome dormancy and seed germination for wild species.

\section{CONCLUSIONS}

$\mathrm{GA}_{3}$ was able to overcome seed dormancy in $P$. suberosa, $P$. morifolia and $P$. tenuifila and $1 \% \mathrm{KNO}_{3}$ was effective for $P$. eichleriana. Mechanical scarification increase germination rates for $P$. micropetala. The other species have not had germination percentage improved by the treatments.

\section{AUTHOR CONTRIBUTION}

TNM: Conception or design of the work, Data collection, Data analysis and interpretation, Drafting the article. PBL: Conception of the work, Data analysis and interpretation, Drafting and Critical revision of the article, Final approval of the version to be published. ART: Data analysis and interpretation, Drafting and Critical revision of the article. LGN: Conception or design of the work, Data analysis and interpretation. SPS: Drafting the article, Critical revision of the rticle.

\section{REFERENCES}

BASKIN, J.M.; BASKIN, C.C. A classification system for seed dormancy. Seed Science Research, v.14, n.1, p.1-16, 2004. DOI: <https://doi.org/10.1079/SSR2003150>

BEWLEY, J.D.; BLACK, M. Seeds: physiology of development and germination. New York: Plenum Press, 1994. 445p.

BRASIL. Regras para análise de sementes. Brasília: MAPA/ACS, 2009. 399p.

CALDAS, C.S.; JUNGHANS, T.G.; SIMÕES, K.S. Germinação in vitro de semente de Passiflora suberosa $L$. Brasília: EMBRAPA, 2008. 356p.

CRUZ, C.D. GENES: A software package for analysis in experimental statistics and quantitative genetics. Acta Scientiarum, v.35, p.271-276, 2013. DOI: <http://dx.doi. org/10.4025/actasciagron.v35i3.21251>

DELANOY, M.; VAN DAMME, P.; SCHELDEMAN, X.; BELTRAN, J. Germination of Passiflora mollissima (Kunth) LH Bailey, Passiflora tricuspis Mast. and Passiflora nov sp. seeds. Scientia Horticulturae, v.110, n.2, p.198-203, 2006. DOI: <http://dx.doi.org/10.1016/j. scienta.2006.07.007>

DOIJODE, S.D. Seed Storage of Horticultural Crops. Boca Raton: CRC Press, 2001. 339p.

FALEIRO, F.G.; JUNQUEIRA, N.T.V.; BRAGA, M.F. Maracujá: germoplasma e melhoramento genético. Planaltina: EMBRAPA Cerrados, 2007. 670p. 
FERREIRA, D.F. SISVAR: um programa para análises e ensino de estatística. Revista Científica Symposium, v.6, p.36-41, 2008.

FERREIRA, G. Propagação do maracujazeiro. Informe Agropecuário, v.21, p.18-24, 2000.

FERREIRA, G.; FOGAÇA, L.A.; BLOEDORN, M. Efeito do ácido giberélico $\left(\mathrm{GA}_{3}\right)$ aplicados em sementes de maracujá-doce (Passiflora alata Dryander) para a produção de mudas em diferentes embalagens. Revista Brasileira de Fruticultura, v.23, p.152-155, 2001.

FONSECA, S.C.L.; SILVA, W.R. Conservação de sementes de maracujá-amarelo: interferências do teor de água das sementes e da temperatura de armazenamento. Bragantia, v.64, n.2, p.273-289, 2005. DOI: <http://dx.doi. org/10.1590/S0006-87052005000200015>

FOWLER, A.J.P.; BIANCHETTI, A. Dormência em sementes florestais. Colombo: Embrapa Florestas, 2000. 27p.

JUNQUEIRA, N.T.V.; VERAS, M.C.M.; NASCIMENTO, A.C.; COSTA CHAVES, R.; MATOS, A.P.; JUNQUEIRA, K.P. A importância da polinização manual para aumentar a produtividade do maracujazeiro. Planaltina: Embrapa Cerrados, 2001. 18p.

LORENZI, H. Frutas brasileiras e exóticas cultivadas: (de consumo in natura). São Paulo: Instituto Plantarum, 2006. 672p.

MAGUIRE, J.D. Seep of germination-aid seedling emergence and vigor. Crop Science, v.2, p.176-177, 1962.

MARTINS, L.; SILVA, W.D.; MELETTI, L.M.M. Conservação de sementes de maracujá-amarelo (Passiflora edulis Sims F. flavicarpa Deg.). Revista Brasileira de Sementes, v. 27, n.1, p.183-189, 2005. DOI: <http://dx.doi. org/10.1590/S0101-31222005000100023>

MELETTI, L.M.M.; FURLANI, P.R.; ÁLVARES, V.; SOARES-SCOTT, M.D.; BERNACCI, L.C.; AZEVEDO FILHO, J.A. Novas tecnologias melhoram a produção de mudas de maracujá. O Agronômico, v.54, n.1, p.30-33, 2002.

MELO, A.L. Comportamento germinativo de espécies de maracujá. Jaboticabal: UNESP, 1998. 8p.
MENDIONDO, G.M.; GARCÍA, M.T.A. Emergence of Passiflora caerulea seeds simulating possible natural destinies. Fruits, v.61, n.4, p.251-258, 2006. DOI: <https:// doi.org/10.1051/fruits:2006022>

PASSOS, I.R.S.; MATOS, G.V.C.; MELETTI, L.M.M.; SCOTT, M.D.S.; BERNACCI, L.C.; VIEIRA, M.R. Utilização do ácido giberélico para a quebra de dormência de sementes de Passiflora nitida Kunth germinadas in vitro. Revista Brasileira de Fruticultura, v.26, n.2, p.380-381, 2004. DOI: https://dx.doi.org/10.1590/S010029452004000200051

PEREIRA, K.J.C.; DIAS, D.C.F.S. Germinação e vigor de sementes de maracujá-amarelo (Passiflora edulis Sims f. flavicarpa Deg.) submetidas a diferentes métodos de remoção da mucilagem. Revista Brasileira de Sementes, v.22, n.1, p.288-291, 2000. DOI: <10.17801/0101-3122/ rbs.v22n1p288-291>

ROSSETO, C.A.V.; CONEGLIAN, R.C.C.; NAKAGAWA, J.; SHIMIZU, M.K.; MARIN, V.A. Germinação de sementes de maracujá-doce (Passiflora alata Dryand) em função de tratamento pré-germinativo. Revista Brasileira de Sementes, v.22, n.1, p.247-252, 2000. DOI: <http:// dx.doi.org/10.17801/0101-3122/rbs.v22n1p247-252>

SANTOS, T.M.; FLORES, P.S.; DE OLIVEIRA, S.P.; DA SILVA, D.F.P.; BRUCKNER, C.H. Tempo de armazenamento e métodos de quebra de dormência em sementes do maracujá-de-restinga. Revista Brasileira de Agropecuária Sustentável (RBAS), v.2, n.1, p.25, 2012.

SOUZA, S.A.M.; MARTINS, K.C.; PEREIRA, T.N.S. Pollinic Preparation For morpho-palynological studies of Passiflora L. Subg. passiflora L. (Passifloraceae). Bioscience Journal, v.31, p.1200-1204, 2015.

TAIZ, L.; ZEIGER, E. Fisiologia vegetal. Porto Alegre: Artmed, 2009. 819p.

WAGNER JÚNIOR, A.; ALEXANDRE, R.; NEGREIROS, J.; PARIZZOTTO, A.; BRUCKNER, C. Influência da escarificação e do tempo de embebição das sementes sobre a germinação de maracujazeiro (Passiflora edulis f. flavicarpa Degener). Revista Ceres, v.52, n.301, p.369378,2006 